\title{
Comparative morphology of two species of Caraguata Bechyné (Coleoptera, Chrysomelidae, Galerucinae, Galerucini)
}

\author{
Elisa von Groll \& Luciano de A. Moura
}

Seção de Zoologia de Invertebrados, Museu de Ciências Naturais, Fundação Zoobotânica do Rio Grande do Sul. Rua Dr. Salvador França, 1427, $90690-000$ Porto Alegre, RS, Brazil (elisavgroll@gmail.com; iucetima@hotmail.com).

Received 13 October 2016.

Accepted 16 November 2016.

DOI: $10.1590 / 1678-4766 e 2017009$

\begin{abstract}
Caraguata Bechyné, 1954 (Galerucini, Galerucina) includes 38 species exclusively Neotropical, among them two sympatric species, $C$. atricornis (Clark, 1865) and C. guaporensis Bechyné, 1958. Given the lack of morphological studies in this group, we aimed to characterize the adult morphology of two species, providing descriptions, illustrations and comparisons of structures of the head, thorax, abdomen and genitalia. The external morphology includes the description of head, thorax, abdomen and its appendices; the internal morphology comprises endosternites, and male and female genitalia. Some similarities were observed, such as pubescence, mouth parts, apparent sexual dimorphism on ventrite V, spermatheca and vaginal palpi. The main differences are in (1) the body and antenna shape, (2) the antenna color pattern, (3) the depression of the pronotum, (4) the presence/absence of the tibial spur, (5) the form of the median lobe, (6) the tegmen and (7) the sternite VIII of the females. The morphological study of these species contributes to the knowledge of Galerucina, presenting important specific characteristics not employed until now. Thus, it can be a contribution for studies of comparative morphology, systematics and evolution of the group.
\end{abstract}

KEYWORDS. Galerucina, Neotropical, Coelomerites, genitalia.

Caraguata Bechyné, 1954 integrates Section Coelomerites (Galerucinae, Galerucini, Galerucina), was established based upon the type species Monocesta sublimbata Baly, 1879. This genus was established to include the species of Monocesta Clark, 1865 with a convex elytra and border with an elevated carina next to the margin, an elytropleural ridge (BECHYNÉ, 1954).

Currently, the genus is composed by 38 species exclusive to the Neotropical region (BECHYNÉ \& BECHYNÉ, 1969, 1970; WiLcox, 1971; Moura, 2016); of these, 25 have been recorded in Brazil, with eight in the Amazonian Region.

When Clark (1865) established Caraguata atricornis without a type-locality, he provided a brief description based solely on external morphological characters. WeISE (1921) also succinctly characterized this species; however, BECHYNÉ (1958) ensured that description was mistaken. In the same study, BECHYNÉ (1958) also presented a key to the identification of species of Caraguata, including C. atricornis and $C$. guaporensis, the latter being newly described from the "Território de Guaporé", currently the state of Rondônia. Due to the lack of detailed morphological characterizations in this group of beetles, we aimed to assess the compared morphology of C. guaporensis and C. atricornis, both distributed in the North of Brazil.

\section{MATERIALS AND METHODS}

The studied material is deposited in the MCNZ, Museu de Ciências Naturais, Fundação Zoobotânica do
Rio Grande do Sul, Porto Alegre, Brazil (Luciano de A. Moura) and in the MPEG, Museu Paraense Emílio Goeldi, Belém, Pará, Brazil (Orlando Tobias and Roberta Valente).

The methods for dissection of genitalia follow MOURA (2009). For the study of the metendosternite, entire specimens were maintained in $10 \% \mathrm{KOH}$ solution at $35^{\circ} \mathrm{C}$ for approximately 24 hours, followed by the individual extraction of the structure.

The terminology follows HÜBLER \& KLASS (2013), LAWRENCE \& ŚLIPIŃSKI (2013) and WiLCOX (1965) for the external and internal (not genitalia) morphology, and Chamorro-Lacayo et al. (2006), Konstantinov (1994), Moura $(1998,2009)$ and Powell (1941) for the genitalia.

\section{RESULTS}

\section{Caraguata atricornis (Clark, 1865)}

(Figs 1, 3, 5, 7, 9, 11, 13, 15, 17, 19, 21, 23, 25, 28-34, 40-44)

Monocesta atricornis CLARK, 1865:318; THAXTER, 1914:39 (biol.); WeISE, 1921:89; BlackWelder, 1946:686 (checklist); Bechyné, 1951:89 (distr.); 1956:288 (distr.) (1956, even after having proposed Caraguata).

Caraguata atricornis: BECHYNÉ, 1954:124; 1958:540 (key); 1969:34 (distr.); WILCOX, 1971:24.

Male. Body (Fig. 1) oblong, sides parallel, somewhat convex in lateral view (Fig. 3). General pattern of coloration from red-brown to dark brown, except for the anntenomeres (variable along the first five), tibiae and tarsi black (except 
for the protibia and tarsi, which only have the lateral external faces black (Fig. 3), due methodology to fixation, specimens present some dark spots.

Head (Fig. 5). Oval, hipognathous, with the same color as the pronotum. Vertex somewhat depressed, integument bright, with shallow puncture and covered with a short golden pubescence and a long setae on the superior inner margin of each eye. Coronal suture well defined. Antennal tubercles weakly evident, with integument smooth and shiny, cordiform and reaching the external lateral side of the antennal insertions. Eyes globose and finely faceted. Gena approximately $1 / 2$ the greatest length of the eye. Antennal sockets round, inserted at the base of the eyes, distance between each other less than their individual diameter. Frontal ridge subtriangular with short apex which reaches the base of the antennal socket, covered by sparse setae. Frontoclypeal suture slim, with sparsely distributed setae. Clypeus transverse, somewhat longer than the frontoclypeal suture. Antennae (Figs 1, 7) 11-segmented, reaching 1/3 of the elytra, black, except for antennomere I of the same color as the head (in some specimens, antennomeres I and II; in other, the interior surface of antennomeres III and/or IV also
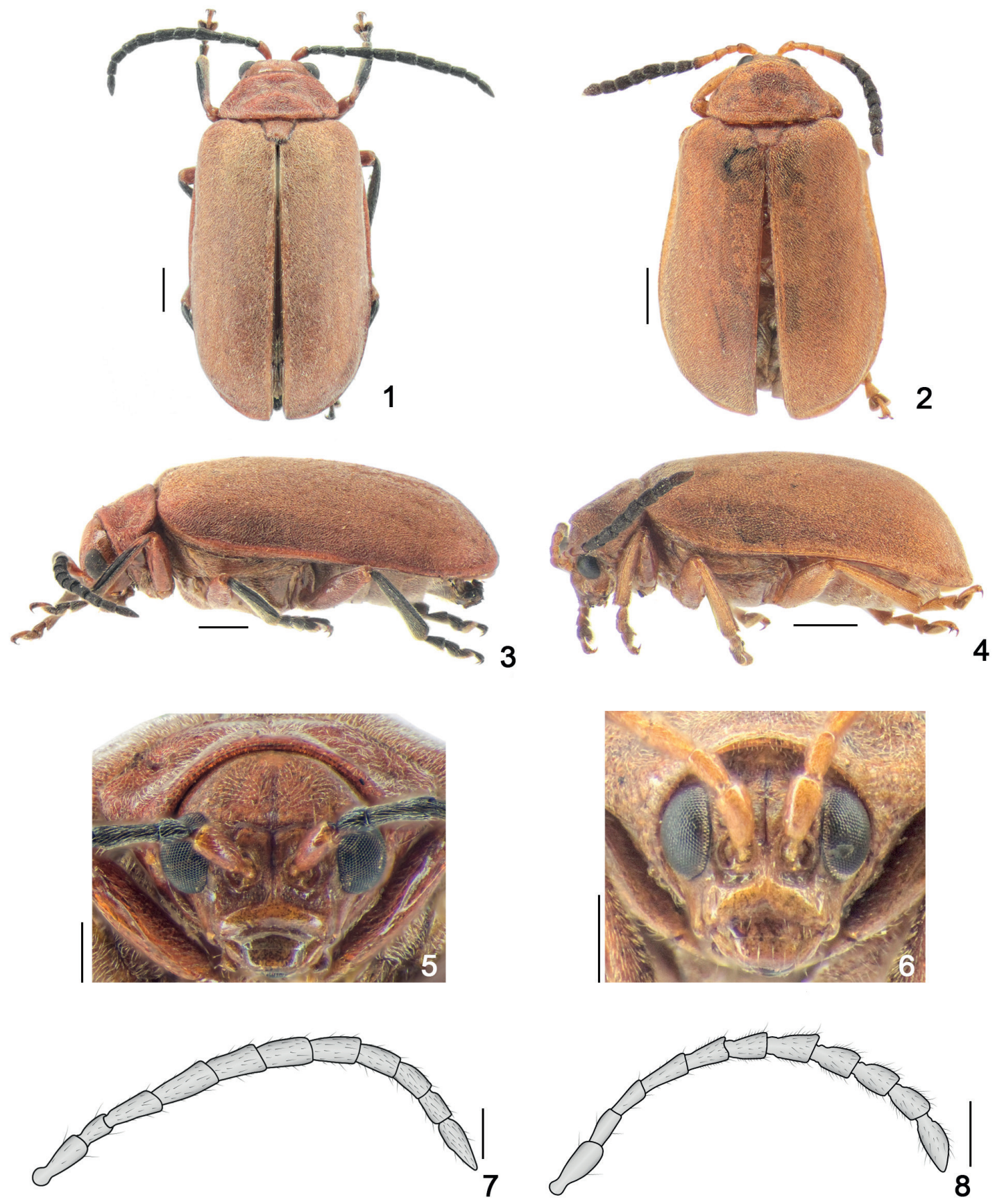

Figs 1-8. Habitus, dorsal view: 1, Caraguata atricornis (Clark); 2, Caraguata guaporensis Bechyné. Habitus, lateral view: 3, C. atricornis; 4, C. guaporensis. Head, frontal view: 5, C. atricornis; 6, C. guaporensis. Antennae: 7, C. atricornis; 8, C. guaporensis. Scale bars: Figs 1-4 =1 mm; Figs 5-8 =0.5 mm. 
with the same color as I). Integument shiny, with general pubescence short, dense and with a few long and sparsely distributed setae, except the scape, which is subglabrous and slightly oblong; scape twice the size of the pedicel, the latter subequal to the length of segments III, V, VII and XI; III slightly shorter than IV; VI somewhat shorter than $\mathrm{V}$ with size tenuously decreasing from VIII to X. Wider at antennomeres V to VIII and, from IX to XI, gradually thinning. Antennomere VII with a small glabrous callus at the apex.

Mouth parts. Labrum (Figs 5, 9) transverse, subrectangular (some specimens with a darker coloration than the head); eight setiferous pores: four laterally and four centrally placed. Mandible (Fig. 11) strongly sclerotized with four subacute teeth, I and IV subequal, II somewhat bigger than I and III, the latter being the biggest. Maxillae (Fig. 13) with few long and sparse setae; stipes divided in basistipes and mediostipes; palpifer well developed; maxillary palp 4-articulated, truncate; palpomere I approximately $1 / 3$ the length of II, the latter slightly longer than III, which is subequal to IV, conival, all with long and sparsely distributed setae; galea subcylindrical, 2-segmented, covered by thin pubescence, reaching the midsection of palpomere IV; lacinia slightly concave, coated by a dense pubescence. Labium (Fig. 15) with mentum transverse, sub-rectangular and two long setae next to palpomeres; palp 3-articulated; palpomere I about half as long as II, the latter subtrapezoidal and somewhat smaller than III, which is conical; ligula (Fig. 15) round with four apical setae.

Pronotum (Figs 1, 17) with similar color to elytra, punctuated and densely pubescent, with greatest width before the middle, approximately 2.3 times wider than long and round lateral margins; two inverted L-shaped depressions originating next to the base, close to the lateral margin, where they are deeper and almost touching each other at center; transversal depression shallow, next to base, not reaching the lateral depressions; each angle bearing a tubercle with a long seta inserted. Prosternum shiny, subglabrous; prosternal process (Fig. 19) laminiform, projected in lateral view. Proendosternite (Fig. 21) membranous, with two divergent and subacuminate apical projections. Mesosternum (Fig. 23) almost reaching the metasternum, shiny, with a short and golden pubescence. Mesepisternum and mesepimeron (Fig. 23) subtrapezoidal with integument shiny and densely
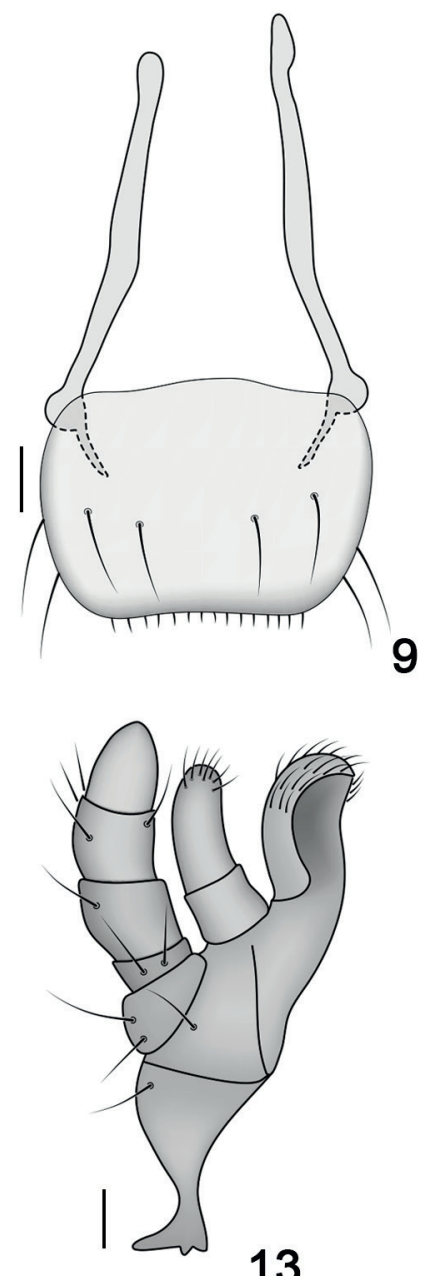

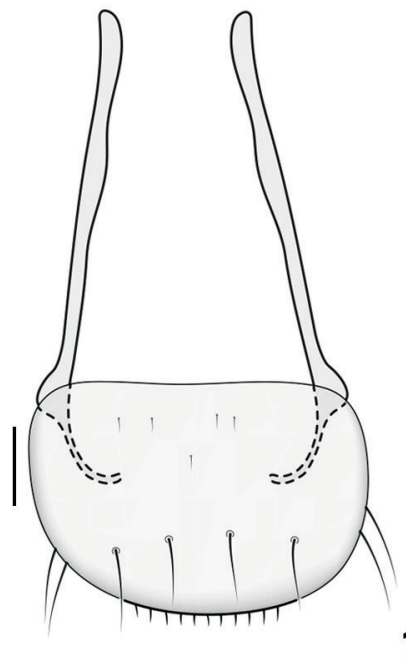

10
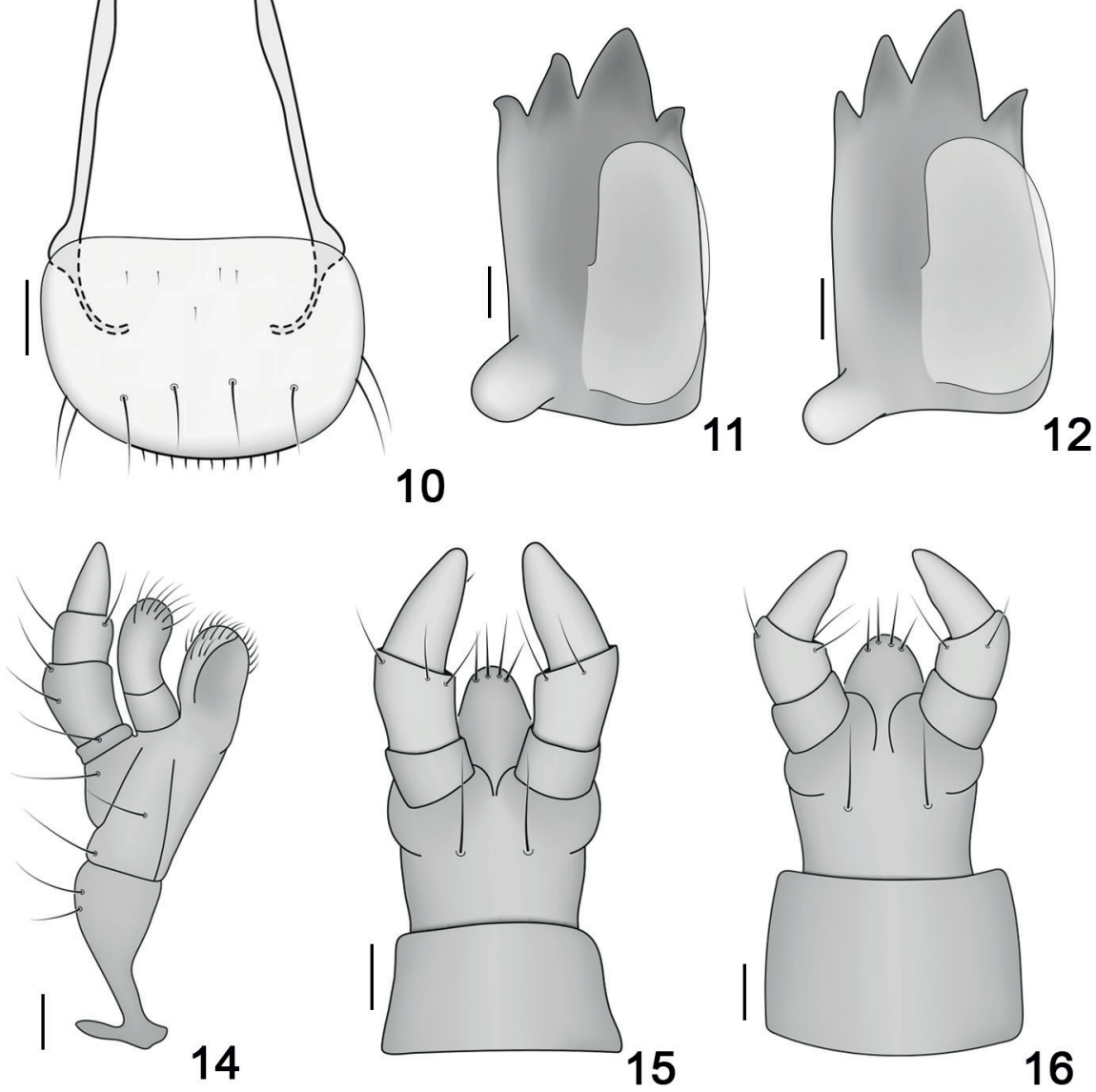

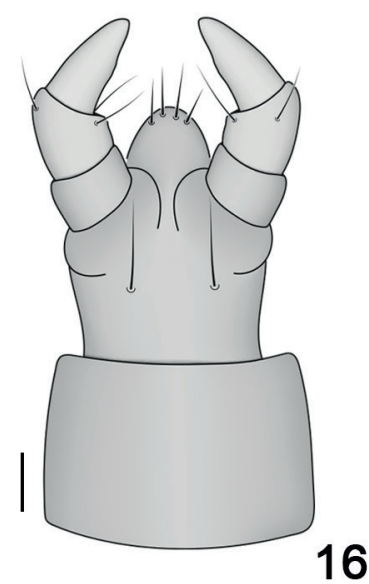

Figs 9-16. Labrum: 9, Caraguata atricornis (Clark); 10, Caraguata guaporensis Bechyné. Mandible, inner view: 11, C. atricornis; 12, C. guaporensis. Maxilla, ventral view: 13, C. atricornis; 14, C. guaporensis. Labium, ventral view: 15, C. atricornis; 16, C. guaporensis. Scale bars =0.1 mm. 
covered by a golden pubescence. Metasternum with same integument of metepisternum, except in the central-basal region, which bears a glabrous surface; width 2.5 times greater than length and approximately 2.3 longer than the mesosternum. Metepisternum (Fig. 23) subtriangular with surface similar to the mesepisternum; metasternal suture almost reaching the superior margin of metasternum. Metendosternite (Fig. 25) with stalk longer than wide; dorsal ridge present; anterior lamina developed, increasing in length until the center; anterior tendon located at $1 / 3$ of the anterior lamina; ventral lamina developed. Scutellum (Fig. 1) subtrapezoidal, slightly longer than wide, with integument similar to pronotum. Elytra (Fig. 1) densely punctuated and pubescent; umeral region developed, round; epipleuron with same pubescence as the elytral surface, widened at metathorax region and gradually narrowed to the $4^{\text {th }}$ ventrite; elytral margins with pubescence short, sparsely and uniformly distributed.

Legs (Fig. 3). Integument shiny. Trochanter subtriangular, almost glabrous; femur subfusiform, with sparse pubescence; tibiae with carina on the external face, without apical spur, densely pubescent, especially in the extremity. Tarsal claws bifid.

Abdomen (Fig. 28) with integument shiny and densely pubescent; ventrite $\mathrm{V}$ with apex folded internally (Figs 28, 29), forming a slightly marked central margin; tergite VII with round apex (Fig. 29).

Genitalia (Figs 29-34). Tergite VIII with round margin and setose apically. Aedeagus (Figs 39-31) with median lobe broad and sclerotized, high curved in lateral view (Fig. 30). Basal region semiarc-shaped, strongly sclerotized, with hook-shaped basal spurs thickened and curved ventrally surrounding the basal orifice (Figs 30, 31); in ventral view it is possible to see the curvature of the median lobe (Fig. 31). Apex truncated (Fig. 31); ostium partially covered by a laminar expansion, the apical hood (Fig. 30), apex round and provided with a few short denticles. Tegmen (Figs 30-33) hastiform, thin; basal apex falciform, inserted in the basal orifice of median lobe and, near the margin, bifurcated in two arms that partially surround the median lobe. Internal
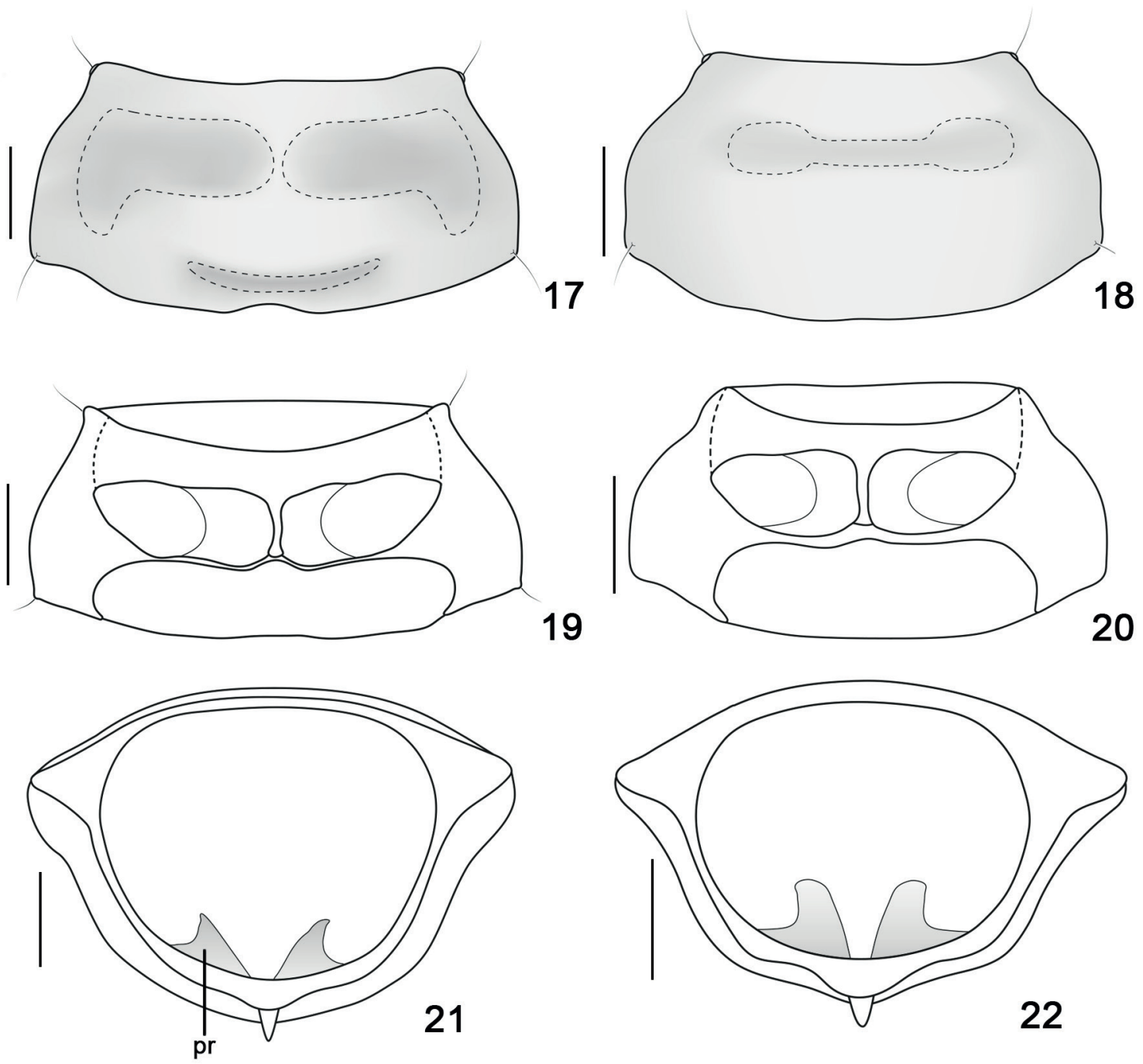

Figs 17-22. Pronotum: 17, Caraguata atricornis (Clark); 18, Caraguata guaporensis Bechyné. Prothorax, ventral view: 19, C. atricornis; 20, C. guaporensis. Proendosternite: 21, C. atricornis; 22, C. guaporensis. (pr, proendosternite). Scale bars $=0.5 \mathrm{~mm}$. 
sac (Fig. 29) membranous with a flagellum with round base and spine-like projection stretching to $1 / 3$ of the total length of the median lobe (Figs 30, 32, 33).

Measurements. Body length 6.2-8.0 mm ( $\mathrm{n}=30$; mean: 7.2); elytral length 5.0-6.4 mm; humeral width 2.9-3.4 mm.

Female. Abdomen with ventrite V (Figs 40, 41) bilobed at apical margin, forming an indentation; tergite VII (Fig. 41) rounded at apex.

Genitalia (Figs 41-44). Tergite VIII (Fig. 41) with apical border slightly truncate. Sternite VIII (Fig. 42) minimally sclerotized, subcylindrical, punctuated, with setae distributed along the apical region, which has a bilobed margin in the central region; apodeme long and thin, with a subtle twist next to the apex, which is somewhat dilated. Vaginal palpi (Fig. 43) digitate, attached by a membrane, with long setae distributed from the central region to the apex. Bursa copulatrix (Fig. 41) sacular and flat; vagina and bursa copulatrix well defined (Fig. 41). Spermatheca (Fig. 44) slightly sclerotized, with the proximal part globose and distal part thin, posteriorly curved and slightly directed laterally; spermathecal gland filiform, attached to the sub- rectangular receptacle.

Measurements. Body length, 7.1-9.0 mm ( $n=34$; mean: 7.9); elytral length, 5.7-7.1 mm; humeral width, 3.2$3.9 \mathrm{~mm}$.

Geographic distribution. Colombia, Venezuela, Guianas, Brazil (Amazonas, Pará) (BECHYNÉ, 1956; 1958; 1969).

Material examined. BRAZIL, Amazonas: Manaus, 2ᄋ, 2.XI.1955; 1 ex., 26.X.1955, Elias \& Roppa col. (MPEG); (Estr. Manaus-Caracaraí, Camp. próx. Igarapé do Leão), ô, 10.V.1961, Dr. Egler col. (MPEG); Pará: P(arque) Tumucumaque, 1 ex., 31.I.1981, E. L. Oliveira col.; Óbidos, đ̃, 1906, P. Le Cointe col. (MPEG); Óbidos (bx./Amazonas, Museu Dirings), 29, V.1958 (MCNZ 238.294, 238.295); Monte Dourado, đ̃, 27.V.1977, W. L. Overal col. (MPEG); Serra Norte (Carajás, Ferrovia do Aço), o, 29.IV.1983, M. F. Torres col. (MPEG); (Pedreira), †, 24.VI.1985, M. Zanuto col. (MCNZ 238.274); §̃, 4, 3 exs, 24.VI.1985, R. D. Thomaz col. (MCNZ 238.276, 238.278, 238.280; MPEG); đ̃, 3 exs, 24.VI.1985, H. Andrade col. (MCNZ
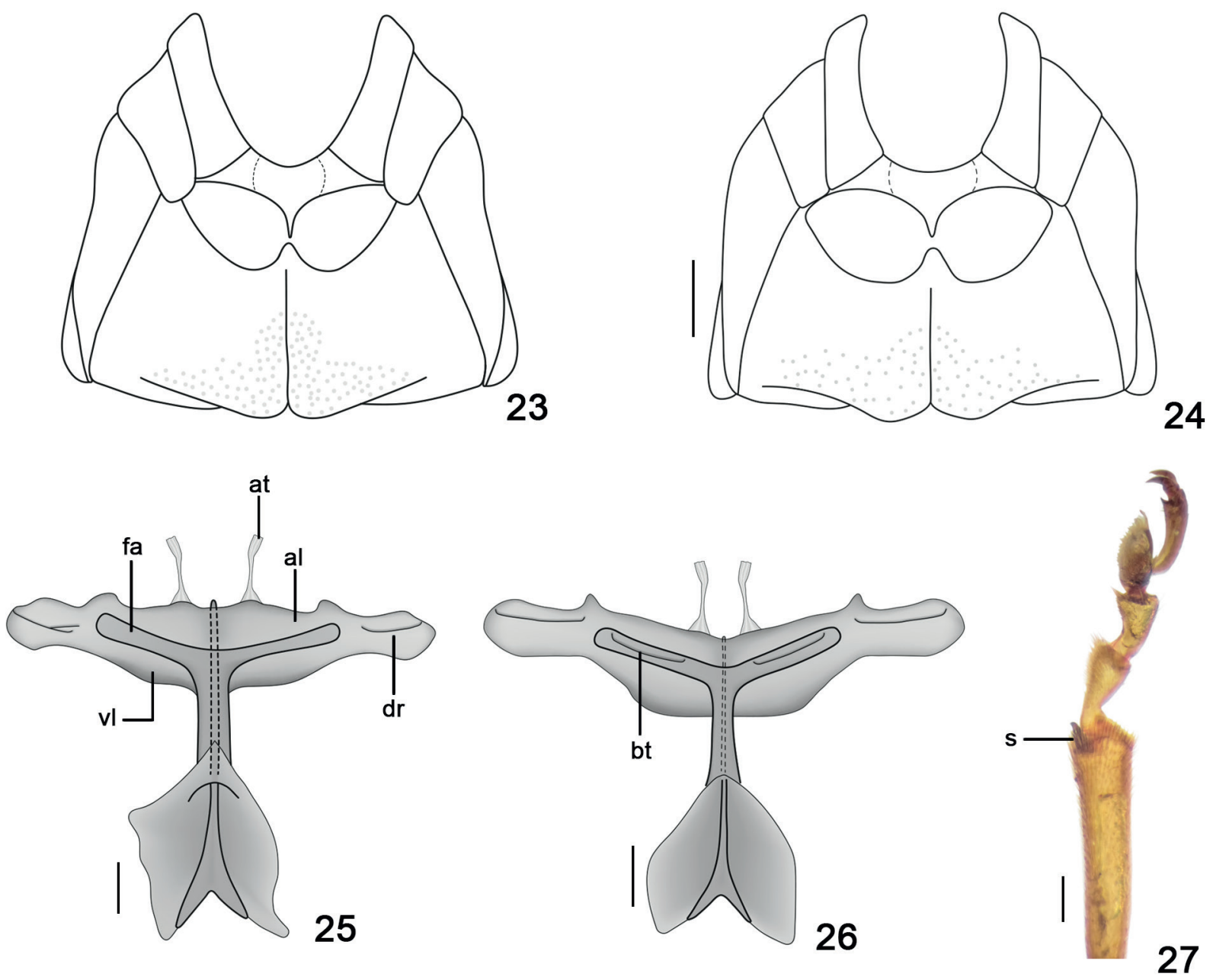

Figs 23-27. Meso- and metasternum: 23, Caraguata atricornis (Clark); 24, Caraguata guaporensis Bechyné. Metendosternite, dorsal view: 25, C. atricornis; 26, C. guaporensis. 27, C. guaporensis, ổ: mesotibiae (al, anterior lamina; at, anterior tendon; bt, basal tendon; dr, dorsal ridge; fa, furcal arm; s, spur; vl, ventral lamina). Scale bars: Figs 23, $24=0.5 \mathrm{~mm}$; Figs $25-27=0.2 \mathrm{~mm}$. 

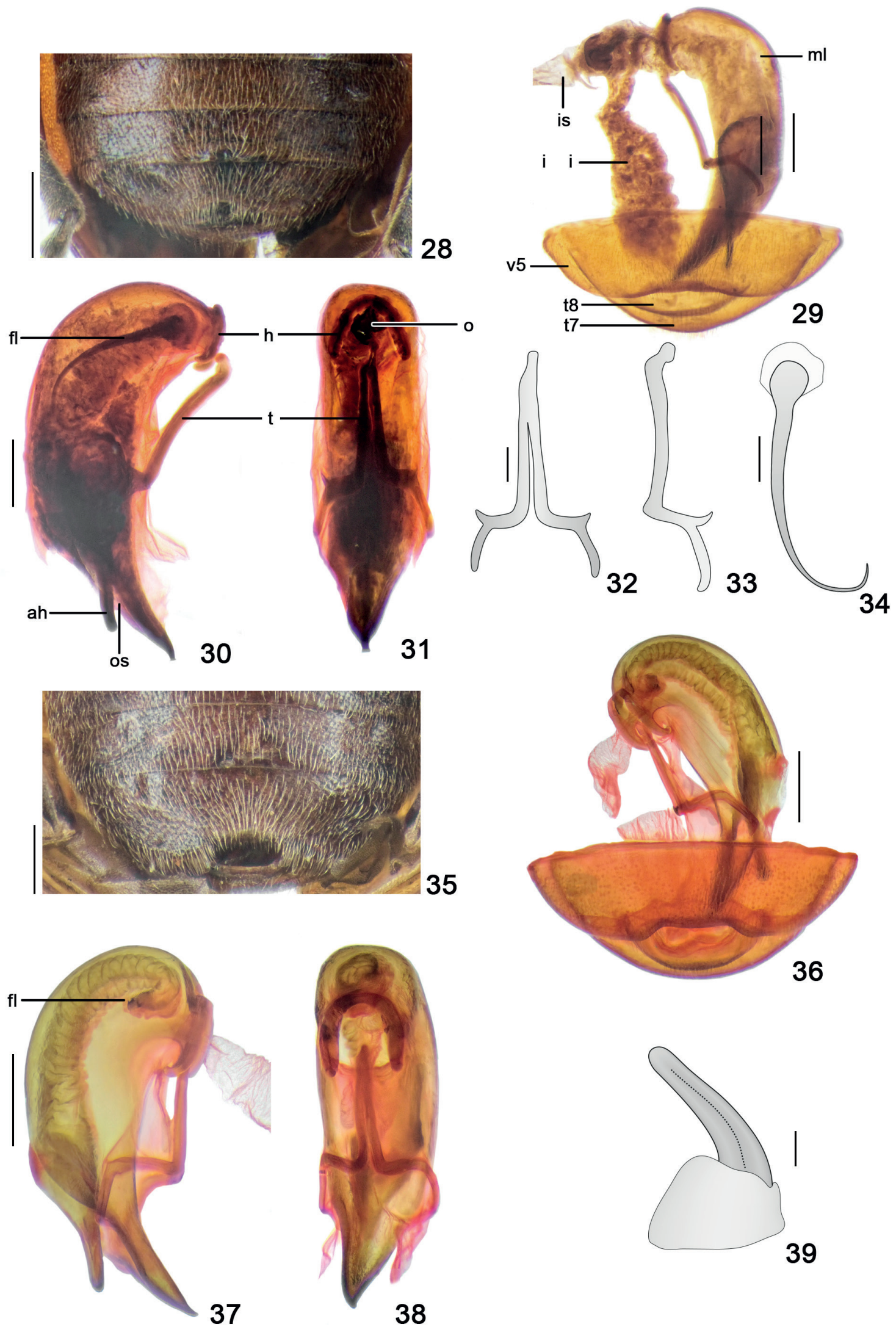

36

Figs 28-39. Caraguata atricornis (Clark), ô: 28, abdomen, ventral view; 29, ventrite V and genitalia; aedeagus: 30, lateral view; 31, ventral view; tegmen: 32 , ventral view; 33, lateral view; 34, flagellum. Caraguata guaporensis Bechyné, § : 35, abdomen, ventral view; 36, ventrite V and genitalia; aedeagus: 37, lateral view; 38, ventral view; 39, flagellum. (ah, apical hood; fl, flagellum; h, hook; i, intestine; is, internal sac; ml, median lobe; o, basal orifice; os, ostium; t, tegmen; t7, tergite VII; t8, tergite VIII; v5, ventrite V). Scale bars: Figs 29-31, 35-38=0.5 mm; Figs 32-34=0.2 mm; Fig. $39=0.1 \mathrm{~mm}$. 

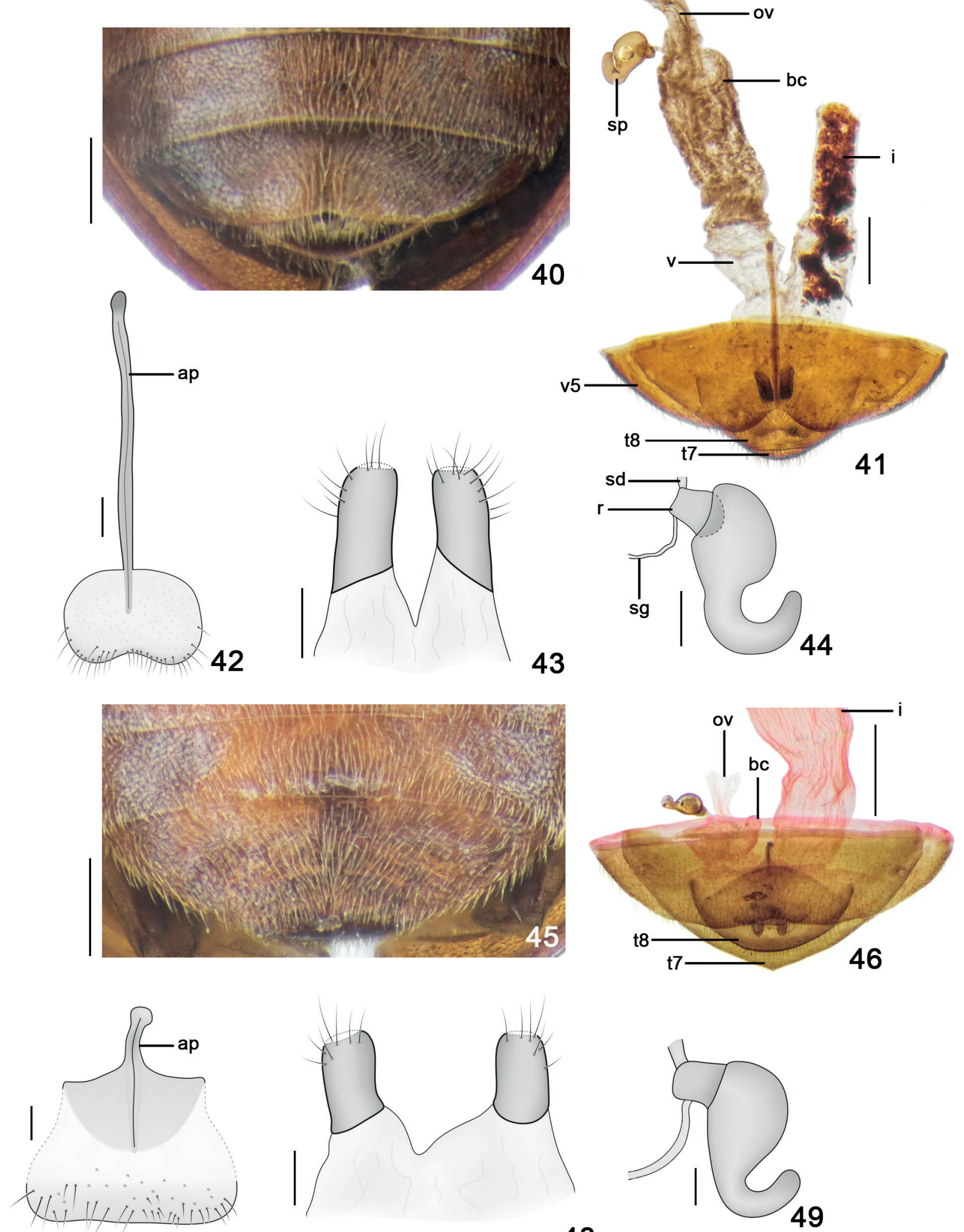

47

48

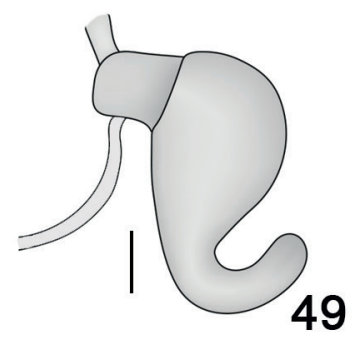

Figs 40-49. Caraguata atricornis (Clark): ㅇ: 40, abdomen, ventral view; 41, ventrite V and genitalia; 42, sternite VIII; 43, vaginal palpi; 44, spermatheca. Caraguata guaporensis Bechyné, o : 45, abdomen, ventral view; 46, ventrite V and genitalia; 47, sternite VIII; 48, vaginal palpi; 49, spermatheca. (ap, apodeme; bc, bursa copulatrix; i, intestine; ov, oviduct; re, receptacle; sd, spermathecal duct; sg, spermathecal gland; sp, spermatheca; t7, tergite VII; t8, tergite VIII; v, vagina; v5, ventrite V). Scale bars: Figs 40, 41, 45, $46=0.5 \mathrm{~mm}$; Figs $42-44=0.2 \mathrm{~mm}$; Figs $47-49=0.2 \mathrm{~mm}$. 
238.281; MPEG); + , 17.VI.1985, P. Tadeu col. (MCNZ 238.275); ㅇ, 3 exs, 17.VI.1985, M. F. Torres col. (MPEG); 2§̂, 27.VI.1986, W. França col. (MPEG); 3ㅇ, 27.IV.1986, J. Dias col. (MPEG); (Fofoca), ふ̄, 25.I.1985, M. F. Torres col. (MCNZ 238.284); ふૈ, 24.IX.1985, M. F. Torres col. (MPEG); 1 ex., 24.IX.1985, M. F. Thomaz col. (MPEG); đ̊, 19.VI.1985, J. Dias col. (MCNZ 238.282); †, 21.VI.1986, J. Dias col. (MPEG); †, 02.VII.1986, J. Dias col. (MPEG); (Estrada da Fofoca), , , 25.I.1985, M. F. Torres col. (MPEG); (Serraria), ô, 21.VI.1985, H. Andrade col. (MCNZ 238.283); 1 ex., 21.VI.1985, H. Andrade col. (MPEG); +, 21.IV.1986, M. F. Torres col. (MPEG); 1 ex., 21.IV.1986, F. F. Ramos col. (MPEG); ふ̃, 30.I.1985, F. F. Ramos col. (MPEG); (Manganês), 2 exs, 17.X.1984, M. Zanuto col. (MPEG); q, 17.X.1984, M. F. Torres col. (MPEG); +, 17.X.1984, T. Pimentel col. (MPEG); đ̄, 27.VI.1985, H. Andrade col. (MPEG); (Manganês; col. noturna), + , 17.VI.1985, R. D. Thomaz col. (MCNZ 238.277); (Pojuca), ふ̋, 16.X.1984, M. F. Torres col. (MPEG); đ̂, 21.VI.1985, H. Andrade col. (MPEG); 1 ex., 2.VII.1985, F. F. Ramos col. (MPEG); (N. 3 Mata), 9 , 18.VI.1985, P. Tadeu col. (MCNZ 238.279); (N. 4), +, 25.VI.1985, N. Bittencourt col. (MPEG); (N4. Ig. do Fogo), q, 25.VI.1985, M. F. Torres col. (MPEG); (3 Alfa), ô, 19.VI.1985, W. França col. (MCNZ 238.279); 우, 20.VI.1985, F. F. Ramos col. (MPEG); (Est. Marganto), 1 ex., 09.IX.1983, M. F. Torres col. (MPEG); Marajó (P. Pedras), 1 ex., 13.III.1978, W. França col. (MPEG); Belém (Marituba), 1 ex., ふ̃, 11.I.1961, J. Bechyné col. (MPEG); (Utinga), 20̂, 22.XII.1960, J. Bechyné col. (MPEG); , 07.V.1977, M. F. Torres col. (MPEG); (Mocambo), +, 23.V.1978, W. França col. (MPEG); (IAN), 1 ex., 22.XII.1960, Inácio col. (MPEG); Belém - Brasília, 1 ex., 27.VII.1972, T. Pimentel col. (MPEG); Belém - Brasília, Km 90 (F. Candiru), đ̃, 27.VII.1972, M. Helena col. (MPEG); ふૈ, 25.VII.1972, R. Dias col. (MPEG); (F. S. Antonio), †, 28.VIII.1972, T. Pimentel col. (MPEG); Benfica, ô, 11.V.1961, J. Bechyné col. (MPEG); Acará, ô, 07.XII.1977; 1 ex., 6.XII.1977, M. F. Torres col. (MPEG); Bujaru, 2ð, 12.V.1978, F. F. Ramos col. (MPEG); ð̊, 21.IV.1979, R. B. Neto col. (MPEG); Benevides, Jै, 16.VI.1961, J. \& B. Bechyné col. (MPEG); (PA-408, Km 06), +, 26.VII.1982, M. F. Torres col. (MPEG); Inhangapi, †, 3.VI.1970, T. Pimentel col. (MPEG); São Francisco do Pará, +, 14.I.1978, M. F. Torres col. (MPEG); Paragominas (PA 70, Km 32), đ̃, 14-15.XI.1979, W. França col. (MPEG); Peixe-Boi, + , 15.IV.1977, P. Waldir col. (MPEG); Bragança, ふૈ, 14.VIII.1977, W. L. Overal col. (MPEG); P. de Pedras, ㅇ, 12.X.1982, M. F. Torres col. (MPEG); 1 ex., 19.X.1982, M. F. Torres col. (MPEG); (Rod. PA-115, Km 20), đ̋ 5.IX.1979, M. F. Torres col. (MPEG).

\section{Caraguata guaporensis Bechyné, 1958}

(Figs 2, 4, 6, 8, 10, 12, 14, 16, 18, 20, 22, 24, 26, 27, 35-39, 45-49)

Caraguata guaporensis BeChyné, 1958:541 (key); BeChyné \& BeChyné, 1969:24 (distr.); WILCOX, 1971:25 (checklist).
Male. Body (Fig. 2) compact, slightly convex in lateral view (Fig. 4), with sub-parallel sides and widened from the basal third of the elytra. General coloration light brown to brown, except for antennomeres V-XI, black (due methods of fixation, some specimens bear irregular dark patches).

Head (Fig. 6) oval, hipognathous, thinner than the pronotum. Vertex somewhat depressed, integument weakly shiny, with thin and sparse puncture, frontal region with short and golden pubescence and a long seta on the superior internal margin of each eye. Coronal suture well defined. Antennal tubercles weakly evident, with integument flat and opaque, forming an inverted triangle, whose wider base reaches the external lateral margin of the antennal insertions. Eyes globose and finely faceted. Gena approximately $1 / 2$ the greatest length of the eye. Antennal sockets round, disposed at the level of the base of the eyes, distance between them inferior to the individual diameter of each antennal socket; region below the antennal socket strongly depressed. Frontal ridge defined, subtriangular, with short apex that reaches the base of the antennal sockets. Frontoclypeal suture thin, with sparsely distributed bristles. Clypeus transverse, subrectangular, about half the length of the labrum. Antennae (Figs 2, 8) 11-segmented, reaching the humeral region; black, except antennomeres I-IV with same coloration as the rest of the body. Integument shiny with short and dense pubescence and a few long setae sparsely distributed, except for the scape and pedicel, which are subglabrous. Antennomeres I, IV e XI subequal in size, II slightly shorter than I and somewhat longer than III; V subtly shorter than IV; VI-X subequal. Antennomeres V to VIII are the widest, and VII with a small callus at apex.

Mouth parts. Labrum (Figs 6, 10) transverse with round sides, with eight setiferous pores: four disposed laterally and four centrally. Mandible (Fig. 12) strongly sclerotized with four subacute teeth, I and IV subequal, II slightly longer than I and III the longest. Maxillae (Fig. 14) with cardo and stipes provided with sparse setae; stipe divided into basistipes and mediostipes; palpifer well developed; maxilar palp thin with four articles; palpomere I approximately $1 / 4$ the length of II, which is longer than III, the latter somewhat smaller than IV, which is conical; all with long and sparsely distributed setae; galea 2-segmented, with round apex covered by thin pubescence, reaching the base of palpomere IV; lacinia round at the apex, somewhat concave, covered by dense pubescence. Labium (Fig. 16) with mentum sub-rectangular, with two long setae next to the palpomeres; labial palp with three articles, provided by long and sparse setae; palpomere I sub-rectangular, about half the length of II, which is subtrapezoidal and slightly smaller than III, conical; ligula (Fig. 16) round with four erect setae at apex.

Pronotum (Figs 2, 18) with surface punctuated and covered by golden pubescence; greatest width before the middle, approximately 1.8 times wider than long and with two small depressions which start laterally and become thinner when reaching the center; each of the angles with tubercles bearing long seta inserted. Prosternum (Fig. 20) 
shiny, subglabrous; prosternal process laminiform, projected in lateral view. Proendosternite (Fig. 22) membranous, with two divergent projections rounded at apex. Mesosternum (Fig. 24) shiny with golden pubescence, short and sparse, almost reaching the metasternum. Mesepisternum and mesepimeron (Fig. 24) subtrapezoidal with the shiny surface covered by golden pubescence, except on the basal region of the mesepimerum. Metasternum (Fig. 24) with integument similar to mesepisternum, except in the central basal region glabrous; width 2.1 times greater than length and approximately 2.8 times longer than mesosternum. Metepisternum (Fig. 24) subtriangular with surface similar to the mesepisternum; metasternal suture almost reaching the superior margin of the metasternum. Metepimeron subtriangular with round angles. Metendosternite (Fig. 26) with stalk longer than wide; dorsal ridge present; anterior lamina developed, with same width until the center; at the $1 / 3$ of the anterior lamina, the anterior tendon is inserted; ventral lamina developed. Scutellum (Fig. 2) sub-squared, with punctuated and pubescent surface. Elytra (Fig. 2) widening after the basal third, densely punctuated and pubescent; humerus rounded; epipleuron pubescent, wide in the region of the metathorax and gradually thinner until the level of the ventrite III; elytral margins with short pilosity, sparsely and uniformly distributed close to the apex.

Legs (Figs 4, 27). Fore legs shorter than the middle legs and hind legs are the longest; integument bright. Trochanter subtriangular, subglabrous; femur subfusiform, pubescent; tibiae and tarsi with dense pilosity. Fore and middle tibiae of males with a small spur ventrally at the apical apex (Fig. 27). Tarsal claws bifid.

Abdomen. Integument shiny and densely pubescent (Fig. 35). Ventrite V with sub-straight margins (Figs 35, 36); tergite VII with round apical margin (Fig. 36).

Genitalia (Figs 36-39). Tergite VIII (Fig. 36) with rounded apex and setae on the apical margin. Aedeagus (Figs 36-38) with median lobe sclerotized, broad and strongly curved in lateral view. Basal region semi-arc shaped, strongly sclerotized, with hook-shaped basal spurs thickened and curved ventrally that demarcate the basal orifice (Fig. 38); apex subacute (Fig. 38); curvature of the median lobe visible in ventral view. Ostium partially protected by the apical hood which, basally, is partially inserted in the median lobe, slightly curved and extrapolating the ostium (Fig. 37). Tegmen (Figs 37,38 ) hastiform, thin; anterior extremity falciform inserted on basal orifice of median lobe and, next to the basal third, bifurcated into two arms which barely envelop the median lobe. Internal sac (Fig. 37) membranous, with a small, short and curved flagellum next to the basal orifice (Fig. 39), continuous to it is the ejaculatory duct (Fig. 37).

Measurements. Body length, 5.7-6.2 ( $\mathrm{n}=10$; mean: 5.9); elytral length, 4.6-5.2 mm; humeral width, 2.8-3.1 mm.

Female. Legs. Tibiae without apical spurs.

Abdomen. Ventrite V (Figs 45, 46) with apical margin slightly sinuous, with a small indentation; extremity of tergite VII acute (Fig. 46).

Genitalia (Figs 46-49). Tergite VIII semicircular with pubescence along the apical margin. Sternite VIII (Fig. 47) sub-rectangular, weakly sclerotized, with sub-straight margin; apical region slightly sclerotized, with puncture and with long setae; region next to the apodeme forming a semicircle somewhat more sclerotized than the apical region; apodeme short and ventrally curved. Vaginal palpi (Fig. 48) digitate, with long setae distributed from the central region to the apex and joined together by a membrane. Bursa copulatrix (Fig. 46) membranous, oviduct inserted next to the median line and, more posteriorly, the spermatheca. Spermatheca (Fig. 49) strongly sclerotized, globose proximally and thinner on the distal part, posteriorly curved and slightly directed laterad; spermathecal gland filiform, attached to the receptacle sub-rectangular.

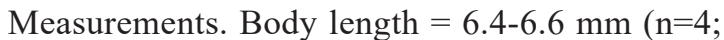
mean: 6.5 ); elytra length $=5.1-5.3 \mathrm{~mm}$; humeral width $=$ 3.0-3.2 $\mathrm{mm}$.

Geographic distribution. Brazil (Rondônia, Amazonas, Pará, Bahia) (Bechyné \& Bechyné, 1969). Because of the lack of information on the labels of the specimens from Bahia (all four are pinned together) and to the origin of the specimens being outside the geographical area previously reported, the record of occurrence to the state of Bahia is considered dubious.

Material examined. BRAZIL, Amazonas: Manaus (1 km, W Taruma Falls),,$~ 11 . I .1981$, G. Ekis col. (MCNZ 238.272); đ̂, VII.1941, Parko col. (MPEG); Rondônia: Vilhena, ô, 26.IX.1986, C. Elias col. (MCZN 238.273); Pará: Belém (IAN), đ̂, 2.VI.1961, J. Bechyné col. (MPEG); (Mocambo), , 20.VI.1978, R. B. Neto col. (MCNZ 238.271); (Parque Ambiental),, , 15.VI.2004, A. L. Nunes e equipe col. (MPEG); Ananindeua, , +, 30.X.1977, M. F. Torres col. (MPEG); Tocantins: Palmas ( $\mathrm{S}^{\mathrm{a}}$. do Lajeado), §, 17.XI.1992, Exp. MCN-MZSP (MCNZ 238.270); (S ${ }^{\mathrm{a}}$. do Lageado, Fazenda Céu), ô, XI.1992, Exp. MCN-MZSP (MCNZ 238.269); Bahia (see geographic distribution above): $4 \hat{\circ}$,, (MPEG).

\section{DISCUSSION}

Both species occur in the North of Brazil and have similarities in the pubescence and color pattern. The body shape of Caraguata atricornis is more elongated and parallel than C. guaporensis.

Caraguata atricornis is larger than C. guaporensis and, even though the average size of males is smaller than in females, there is no clear size distinction between the two sexes as observed in C. guaporensis, where males are smaller than the females. BECHYNÉ (1958) mentioned specimens of $C$. atricornis whose length was between 6 and $8 \mathrm{~mm}$, while WeISE (1921) examined individuals with 5 to $8 \mathrm{~mm}$. The length of the specimens studied here vary from 6.2 to $9 \mathrm{~mm}$. Quite frequently, C. atricornis is mistaken with $C$. nigricornis (Clark, 1865), but the former is smaller, with a lighter red color, body shape parallel and less convex, with all antennomeres black (CLARK, 1865; BeCHYNÉ, 1958).

Head. Clark (1865) described C. atricornis (in 
Monocesta) with only antennomere I bearing a different color pattern from the rest of the antenna; however, we have examined specimens with the antennomeres II and/or III also differently colored. On the other hand, all individuals of C. guaporensis have only one pattern: antennomeres I-IV with different coloration than the others; furthermore, this species also bears more compact antennomeres, meaning that the height-width proportion is smaller, and the antennal tubercles are more evident in C. atricornis.

Both species have mouthparts typical of Galerucini (NADEIN \& BEZDÉK, 2014), with small differences in shape and proportions. Caraguata atricornis has a more rectangular labrum and maxillary palp more robust than C. guaporensis, who bears more developed galea and labial palp.

The pronotum of $C$. atricornis shows two big L-shaped depressions and a smaller one next to the base, transversal; in C. guaporensis such depression are more subtle and the referred transversal at the base is not present. As for the size, both the prothorax and the metathorax have a greater difference in the proportion between width and height in C. atricornis, being more compact in C. guaporensis. The proendosternite has a different apex: round in C. guaporensis and slightly acute in C. atricornis. In addition to the genitalia, the metendosternite is one of the few internal structures used in Coleoptera systematics (HüBLER \& KLASS, 2013); generally speaking, the structure is similar in both species, but $C$. guaporensis has the basal tendon on the arms and ventral lamina slightly more developed. The elytropleural ridge is wider in C. guaporensis.

In Caraguata atricornis the color is different on femora, tibiae and tarsi, whereas in C. guaporensis the pattern is uniform along these leg structures. The most significant difference between them is that males of $C$. guaporensis present meso- and metatibial apical spurs (absent in females); such sexual dimorphism is not verified in C. atricornis, who has inermous tibiae in both sexes. This dimorphism was also observed in C. circumcincta (Clark, 1865) and $C$. onca Moura, 2016; however, in these two, only the middle tibiae are provided with spur (Moura, 2009; 2016); C. bella (Bechyné, 1951) has also inermous tibiae in both sexes (CABRERA \& Durante, 2004).

The ventrite $\mathrm{V}$ of males of both species have a slightly folded apex which forms a margin, however, this characteristic is more evident in C. guaporensis. Furthermore, the tergites VII and VIII are rounded in both species. The median lobe in C. guaporensis is wider and more curved than C. atricornis; Moura $(2005 ; 2016)$ and CABRERA \& DURANTE (2004) respectively described median lobes thin and long in C. circumcincta, C. onca and C. bella. As for the hook-like structures on the basal portion, when observed ventrally, in C. atricornis they are slightly divergent, whereas in $C$. guaporensis those are subparallel. The function of these hook-like formations is to attach to the last abdominal segment, preventing the total extroversion of the median lobe during mating (VERMA, 1969); until now, in Galerucini, these structures appear to be exclusive to Galerucina and Metacyclina, spanning all studied species (Powell, 1941;
Wilcox, 1965; Lesage, 1986, Cabrera \& DuRANTE, 2004; Moura, 2009). Both C. atricornis and C. guaporensis have a well defined ostium, which is partially protected by the apical hood; such structure, which is more developed in the first species, was not observed in C. circumcincta, C. onca and C. bella (Moura, 2005; 2016; Cabrera \& Durante, 2004). The tegmen follows the pattern of the more evolved chrysomelids - it doesn't form a complete ring enveloping the median lobe, only one structure bifurcated in two arms (LAWRENCE et al., 1995); on these arms, C. atricornis bears acuminate projections, in a configuration similar to that described by Verma (1969) for Galerucella birmanica (Jacoby, 1889) (Galerucini); these have not been recorded for $C$. guaporensis. In the internal sac, CABRERA \& DURANTE (2004) and Moura (2005) observed a long structure with a dentate apex, very similar between the species; this formation was not observed in the species studied here. Caraguata guaporensis and C. atricornis have a flagellum in the internal sac, with the one in the latter species being thinner and longer; this structure is an extension of the ejaculatory duct (Torre-Bueno, 1989) which helps in the transference of sperm (MANn \& Crowson, 1996) and was not referred to C. bella neither for $C$. circumcincta (CABRERA \& DURANTE, 2004; Moura, 2005).

Ventrite $\mathrm{V}$ in females bears a conspicuous difference between the two species: the apical margin in C. atricornis is well delineated and in C. guaporensis is less evident; a slightly marked bilobed formation was also observed by Cabrera \& Durante (2004) in C. bella. In C. atricornis the borders of tergites VII and VIII are round and of subtruncate, respectively, while in C. guaporensis both are, also respectively, acute and round. Sternite VIII is the structure with the most evident difference, being slightly bilobed on the apical margin and bearing a long apodeme in C. atricornis, while the apical margin is sub-straight and the apodeme is short in C. guaporensis. Ventrite V in Caraguata circumcincta is subtrapezoidal and without an apodeme (Moura, 2005), while in C. bella it is nearly triangular with apodeme long and slender CABRERA \& DURANTE (2004). When reviewing Ophraella (Galerucini, Galerucina), LESAGE (1986) also found significant differences in the sternite VIII and ascertained that the structure could be used to differentiate the species. The shape of the vaginal palpi are similar both in the two species studied here (while slightly longer than in C. atricornis) as in the two characterized by Moura (2005) and CABRERA \& DURANTE (2004); the same comparison can be seen when assessing the spermathecal: in $C$. atricornis the distal part is slightly longer than in C. guaporensis.

Acknowledgements. We thank the Brazilian Research Council (CNPq) for providing the research fellowship to EvG and the curator of the MPEG, for the loan of the examined material.

\section{REFERENCES}

BECHYNÉ, J. 1951. Chrysomeloidea americains nouveaux ou peu connus. Revista Chilena de Entomología 1:75-112. 
BeChyné, J. 1954. Über die in Matto Grosso von F. Plaumann gesammelten Chrysomeloidea (Col. Phytophaga). Entomologische Arbeiten 5:116133.

Bechyné, J. 1956. Reise des Herrn G. Frey in Südamerika: Galerucidae (Col. Phytophaga). Entomologische Arbeiten 7:241-358.

Bechyné, J. 1958. Notizen zu den neotropischen Chrysomeloidea (Col. Phytophaga). Entomologische Arbeiten 9:478-706.

BeChyné, J. 1969. Notas sobre Phytophaga americanos (Coleoptera). Revista de la Facultad de Agronomia de la Universidad Central de Venezuela 5(3):5-64.

Bechyné, J. \& Bechyné, B. S. DE. 1969. Die Galerucidengattungen in Sudbrasilien. Iheringia, Série Zoologia 36:3-110.

Bechyné, J. \& Bechyné, B. S. DE. 1970. Beiträge zur Kenntnis der Insektenfauna Boliviens XX. Coleoptera XV. Beiträge zur Galerucidenfauna Boliviens. Veröffentlechungen de Zoologischen Staatssammlung München 14:121-190.

BlACKWELDER, R. E. 1946. Checklist of the coleopterous insects of Mexico, Central America The West Indies, and South America. Bulletin of the United States National Museum 185(4):551-763.

Cabrera, N. \& Durante, S. 2004. The Neotropical Genus Caraguata Bechyné: Description of the Previously Unknown Male of Caraguata bella Bechyné (Coleoptera: Chrysomelidae: Galerucinae). Transactions of the American Entomological Society 30(2/3):155-163.

Chamorro-Lacayo, M. L.; Konstantinov, A. S. \& Moseyko, A. G. 2006. Comparative morphology of the female genitalia and abdominal structures of Neotropical Chryptocepahlini (Coleoptera: Chrysomelidae: Chryptocephalinae). The Coleopterists Bulletin 60(2):113-134.

Clark, H. 1865. An examination of the Dejeanian Genus Coelomera (Coleoptera Phytophaga) and its affinities. The Annals and Magazine of Natural History 16(3):315-325.

HüBLER, N. \& KLASS, K.-D. 2013. The morphology of the metendosternite and the anterior abdominal venter in Chrysomelinae (Insecta: Coleoptera: Chrysomelidae). Arthropod Systematics \& Phylogeny 71(1):3-41.

Konstantinov, A. 1994. Comparative morphology and some evolutionary trends in flea beetles (Alticinae). In: Jolivet, P. H., Cox, M. L. \& Petitpierre, E. eds. Novel aspects of the biology of Chrysomelidae. Kluwer Academic Publishers, The Netherlands, p. 383-391.

Lawrence, J. F. \& ŚlipińsKi, A. 2013. Australian Beetles. Vol 1: Morphology, Classification and Keys. Collingwood, CSIRO Publishing. 561p.

Lawrence, J. F.; Ślipiński, A. \& Pakaluk, J. 1995. From Latreille to Crowson: a history of the higher-level classification of beetles. In: PAKAluK, J. \& ŚliPíNSKI, A. eds. Biology, Phylogeny, and Classification of Coleoptera. Warszawa, Muzeum i Institut Zoologii PAN, p. 87-154.
LeSAGE, L. 1986. A taxonomic monograph of the Nearctic galerucine genus Ophraella Wilcox (Coleoptera: Chrysomelidae). Memoirs of the Entomological Society of Canada (133):1-75.

MANn, J. S. \& CROwson, R. A. 1996. Internal sac structure and phylogeny of Chrysomelidae. In: Jolivet, P. H. A. \& Cox, M. L. eds. Chrysomelidae Biology, vol 1: The Classification, Phylogeny and Genetics. Amsterdam, Academic Publishing, p. 291-316.

MourA, L. DE A. 1998 Iucetima, gênero novo de Galerucini da Região Neotropical (Coleoptera, Chrysomelidae, Galerucinae). Iheringia, Série Zoologia (85):75-88.

Moura, L. DE A. 2005. Novos táxons em Galerucini e redescrição de Caraguata circumcincta Clark (Coleoptera, Chrysomelidae, Galerucinae). Revista Brasileira de Zoologia 22(4):1109-1115.

MourA, L. DE A. 2009. Morfologia comparada da genitália masculina de Galerucini (Coleoptera, Chrysomelidae, Galerucinae). Revista Brasileira de Entomologia 53(1):15-29.

MourA, L. DE A. 2016. New species, new combinations and synonymies of Neotropical Galerucini (Coleoptera, Chrysomelidae, Galerucinae). Zootaxa 4066(1):63-70.

NADEIN, K. S. \& BEZdÉK, J. 2014. Galerucinae Latreille, 1802. In: LESCHEN, R. A. B. \& Beutel, R. G. eds. Handbook of Zoology, Arthropoda: Insecta, Coleoptera, Beetles. Volume 3: Morphology and Systematics (Phytophaga). Berlin/Boston, de Gruyter, p. 251-259.

Powell, E. F. 1941. Relationships within the Family Chrysomelidae (Coleoptera) as indicated by the male genitalia of certain species. American Midland Naturalist 25:148-195.

Thaxter, R. 1914. Laboulbeniales Parasitic on Chrysomelidae. Proceedings of the American Academy of Arts and Sciences 50(2):17-50.

Torre-Bueno, J. R. DE LA. 1989. The Torre Bueno Glossary of Entomology. New York, New York Entomological Society. 840p.

Verma, K. K. 1969. Functional and developmental anatomy of the reproductive organs in the male Galerucella birmanica Jac. (Coleoptera, Polyphaga, Chrysomelidae). Annales des Sciences Naturalles, Zoologie 11:139-234

Weise, J. 1921. Wissenschaftlich Ergebnisse der schwedischen entomologischen Reise des Herrn Dr. A. Roman in Amazonas 19141915. 6. Chrysomelidae. Arkiv för Zoologi 14:1-205.

Wilcox, J. A. 1965. A synopsis of the North American Galerucinae (Coleoptera: Chrysomelidae). Bulletin of th New York Museum and Science Service 400:1-226.

Wilcox, J. A. 1971. Coleopterorum Catalogus. Supplementa, Chrysomelidae: Galerucinae, 2 ed., s'-Gravenhage, W. Junk, v.78(1). 220p. 